Immanuel Kant's Groundwork for the Metaphysics of Morals 



\section{Immanuel Kant's Groundwork for the Metaphysics of Morals A Commentary}

Dieter Schönecker and Allen W. Wood

Translated by Nicholas Walker

II Harvard University Press

Cambridge, Massachusetts / London, England / 2015 
Copyright (C) 2015 by the President and Fellows of Harvard College All rights reserved

Printed in the United States of America

First Printing

Originally published in German as Immanuel Kant Grundlegung zur Metaphysik der Sitten: Ein einfürbrender Kommentar, copyright (C) 2002 Verlag Ferdinand Schöningh GmbH \& Co. KG, Paderborn.

The translation of this text was made possible by the generous financial support of The University of Siegen

\section{Library of Congress Cataloging-in-Publication Data}

Schönecker, Dieter.

Immanuel Kant's groundwork for The metaphysics of morals : a commentary / Dieter Schönecker and Allen W. Wood.

pages $\mathrm{cm}$

Includes bibliographical references and index.

ISBN 978-o-674-43013-6 (alk. paper)

I. Kant, Immanuel, I724-1804. Grundlegung zur Metaphysik der Sitten.

English. 2. Ethics. I. Title.

$\mathrm{B}_{27} 66 . \mathrm{Z}_{7} \mathrm{~S}_{27} \quad 2014$

I70-dc23 2014007806 
For Rega und Rica 
